\title{
ASSESSMENT THE HYDROCARBON POTENTIALITY OF THE MIDDLE JURASSIC SARGELU FORMATION, NORTHERN IRAQ
}

\author{
${ }^{1}$ Swar J. Al-Atroshi, ${ }^{2}$ Govand H. Sherwani ${ }^{*}$ and ${ }^{3}$ Srood F. Al-Naqshbandi \\ ${ }^{1 \& 2}$ Department of Geology, Salahaddin University, Erbil, Iraq \\ ${ }^{3}$ Department of Civil Engineering, Cihan University-Erbil, Iraq \\ *E-mail: govand.sherwani@ cihanuniversity.edu.iq \\ Received: 3 July 2019; accepted: 14 September 2019
}

\begin{abstract}
The Middle Jurassic Sargelu Formation is evaluated for its hydrocarbon generation potential in three wells near Duhok Governorate, Northern Iraq using ten borehole cutting samples analyzed by RockEvil pyrolysis, gas chromatography coupled with gas chromatography-mass spectrometry (MSS) and stable isotope. The results showed that the total organic carbon and genetic potential of the formation ranges from 0.5 to $11.6 \mathrm{wt} . \%$ and 1.7 to $66.3 \mathrm{mg} \mathrm{HC/g}$ of rock, respectively indicating fair to excellent source rock petroleum potential, with hydrogen index values between 270 to $555 \mathrm{mg} \mathrm{HC/g} \mathrm{TOC.} \mathrm{The}$ results also show kerogen Types II and mixed II/III reflecting thermal maturity within the oil generation zone. The estimated ratios of $\mathrm{Pr} / \mathrm{Ph}, \mathrm{Pr} / \mathrm{n}-\mathrm{C}_{17}$ and $\mathrm{Ph} / \mathrm{n}-\mathrm{C}_{18}$ from the extracted bitumen reveal primary accumulations of marine organic matter under reducing conditions. The $\delta^{13} C_{\text {Sat }}$ and $\delta^{13} C_{\text {Aro }}$ for the extracted bitumen range from -29.5 to $-27.5 \%$ and -28.4 to $-27.2 \%$, respectively. The biomarkers results indicate a significant contribution of marine organic matters preserved under relatively anoxic conditions.
\end{abstract}

Keywords: Sargelu; Rock-Eval; NW Iraq; Middle Jurassic; Biomarker

\section{INTRODUCTION}

The northern part of Iraq is characterized by multiple source rocks, one of these is rocks Sargelu Formation (Pitman et al., 2004). The formation has been studied in detail for its lithology and stratigraphy by Wetzel (1948) (Bellen et al., 1959). 
The identification of a petroleum source rock can be established by determination of organic matter richness (quantity), type of kerogen (quality) and eventually, the maturity of source rock (Tissot and Welte, 1984, Waples, 1985 and Hunt, 1996). The Middle Jurassic deposits have been considered as potential source rocks for hydrocarbons deposited under the euxinic environment in the Middle East (Murris, 1980 and Beydoun, 1986) and in the Kurdistan Region of Northern Iraq (Al-Ameri et al., 2014, English et al., 2015 and Hakimi \& Najaf, 2016).

Biomarkers studies are very helpful because they can provide information on the organic matter $(\mathrm{OM})$ in the source like environmental conditions during its deposition and thermal maturity experienced by rock or oil (catagenesis), the degree of biodegradation along with some aspects of source rock with deposition environment, and age (Peters \& Moldowan, 1993).

The possible petroleum source rocks of Jurassic and Cretaceous in Northern Iraq is still and will remain an active research area to establish the source of crude in the reservoir and their conditions of deposition. The current research is an effort in that line based on geochemical studies including RockEval pyrolysis, gas chromatography (GC), stable carbon isotope and gas chromatography-mass spectrometry (GC-MSS) analysis. The main aims are to investigate total organic carbon (TOC), pyrolysis, residual oil extractions and biomarker fingerprints of the Middle Jurassic Sargelu Formation to provide details on the origin of OM, thermal maturity and depositional environment.

\section{GEOLOGICAL SETTING}

This study is the first one conducted on the Middle Jurassic Sargelu Formation in three wells in northwestern Iraq; Mangesh-1 (Ma-1), Atrush-1 (At-1) and Shaikhan-8 (Sh-8) wells (Fig. 1). Iraqi Kurdistan Region forms the NE boundary of the Arabian Plate (AP) and is a part of the Alpine Mountain Belt. This belt has an E-W trend in the northern part and NW-SE trend in the northeastern part (Jassim and Buday, 2006). The study area is a part of the Zagros Basin and representing the so-called Zagros Fold Belt of Northern Iraq (Ameen, 1992). Zagros basin is a narrow belt that extends from northern Iraq to the Arabian Gulf. Two main sectors are identified within the Taurus-Zagros Belt; the Thrust Zone and the Folded Zone (Ameen, 1992) (Fig. 2). The Folded Zone has been subdivided into two zones based on folding intensity (Jassim and Goff, 2006). They are (1) the High Folded Zone, which consists of a series of NW-SE trending, mostly asymmetrical anticlines separated by narrower synclines characterized by steeper southern or southwestern limbs; and (2) the Foothill Zone which is characterized by low altitude hills and relatively smaller anticlines and synclines where the prominent Hemrin-Mekhul mountain chain 
forms its southwestern boundary, separating it from the Mesopotamian Zone. Atrush and Shaikhan oilfields are located in the High Folded Zone, a part of the Zagros Fold and Thrust Belt of Iraq, some 85 $\mathrm{km}$ northwest and $60 \mathrm{~km}$ north of Erbil city respectively. Both are recent oil discoveries in the Kurdistan Region of Iraq. The Atrush structure is a NW-SE oriented, doubly-plunged asymmetrical anticline, and its northeastern limb is gentler than the southwestern one (Al-Naqib, 1980).

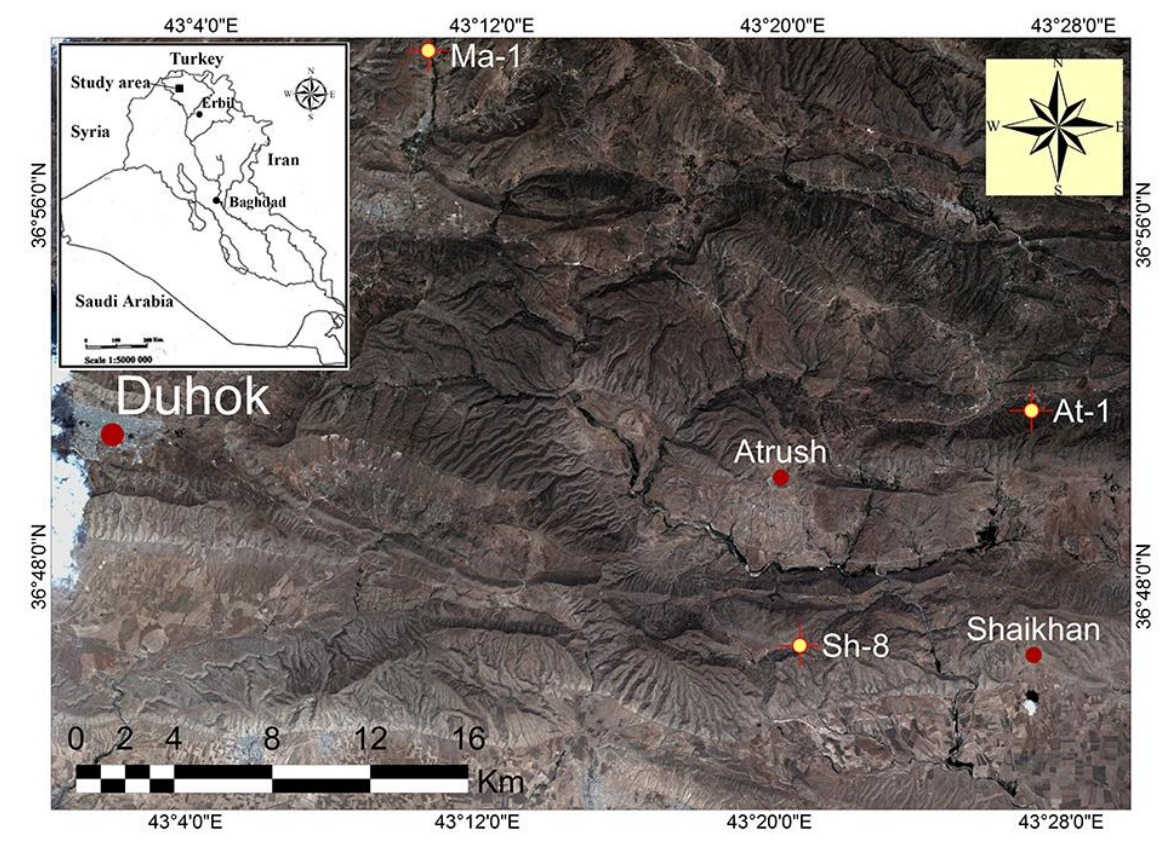

Fig. 1: Landsat image showing the location of the studied wells, Ma-1, At-1 and Sh-8

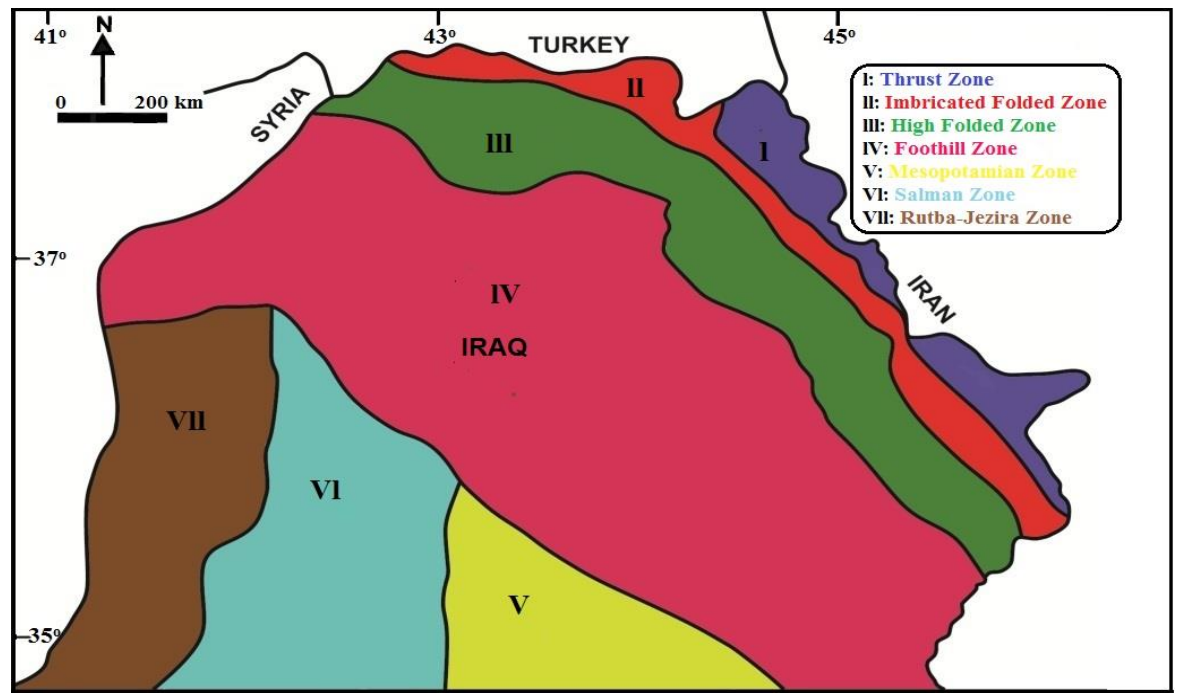

Fig. 2: Tectonic Map of Northern Iraq (redrawn after Buday, 1980 and Ameen, 1992) 
The Shaikhan anticline is a WNW-ESE trending doubly-plunged asymmetrical anticline, with a gentle southwestern limb and steeper back limb. This fold is considered as an open structure due to its interlimb angle of $120^{\circ}$ (Al-Azzawi and Hamdoon, 2008). During the Jurassic period, all Northern Iraq lands were considered parts of an intrashelf compartment that was geometrically separated from the basin physiography (Jassim and Goff, 2006) and many formations were deposited in the intrashelf and basins. The first description of the Sargelu Formation was introduced by Wetzel (1948) from an outcrop of about 115 m thick at Surdash Anticline, Sulaimaniya area within the High Folded Zone of Iraq (Bellen et al., 1959).

The Middle Jurassic Sargelu Formation generally crops out at some limbs and cores of structures in the Highly Folded Zones of Northern Iraq (Buday, 1980). This formation represents the basal supersequence (Upper Aalenian-Bathonian) of the Megasequence AP7 which includes Alan, Sargelu, Naokelekan and Barsarin formations.

The stratigraphic successions exposed within the studied well-sections include Jurassic Alan, Sargelu, Naokelekan and Barsarin formations from the oldest to youngest. Younger Cretaceous units are comprised of Chia Gara, Garagu, Sarmord, Qamchuqa, Kometan, Wajna, and Aqra formations. These were further overlain by the Tertiary succession comprised of Kolosh, Gercus and Pila Spi formations.

The outcrops of Sargelu Formation in several localities such as Banik, Gara, and Naokelekan consist of thinly bedded black bituminous limestone, interbedded with dolomitic limestone and black papery shale intercalated by thin black, streaks of chert nodules in the uppermost part of the formation (Balaky, 2004). This formation in Iraq was probably deposited under sulphate-reducing marine conditions (Murris, 1980; Al-Ameri and Zumberge, 2012; Al-Ameri et al., 2014).

The lithologic description of the Sargelu Formation is based on the subsurface sections in this study (Fig. 3). The Mangesh-1 well (Ma-1) section shows different lithologies such as calcareous dolomite, dolomitic limestone and limestone. In Atrush-1 well (At-1), the lithology is dominated by a combination of fine-grained limestone, and light grey to dark grey shale. The limestone fraction contains calcite and some anhydrite. However, in well Shaikhan-8 (Sh-8), the formation consists of fine-grained limestone, argillaceous limestone interbedded with thin layers of anhydrite and limestone intercalated with marl and shale (Fig. 3). 


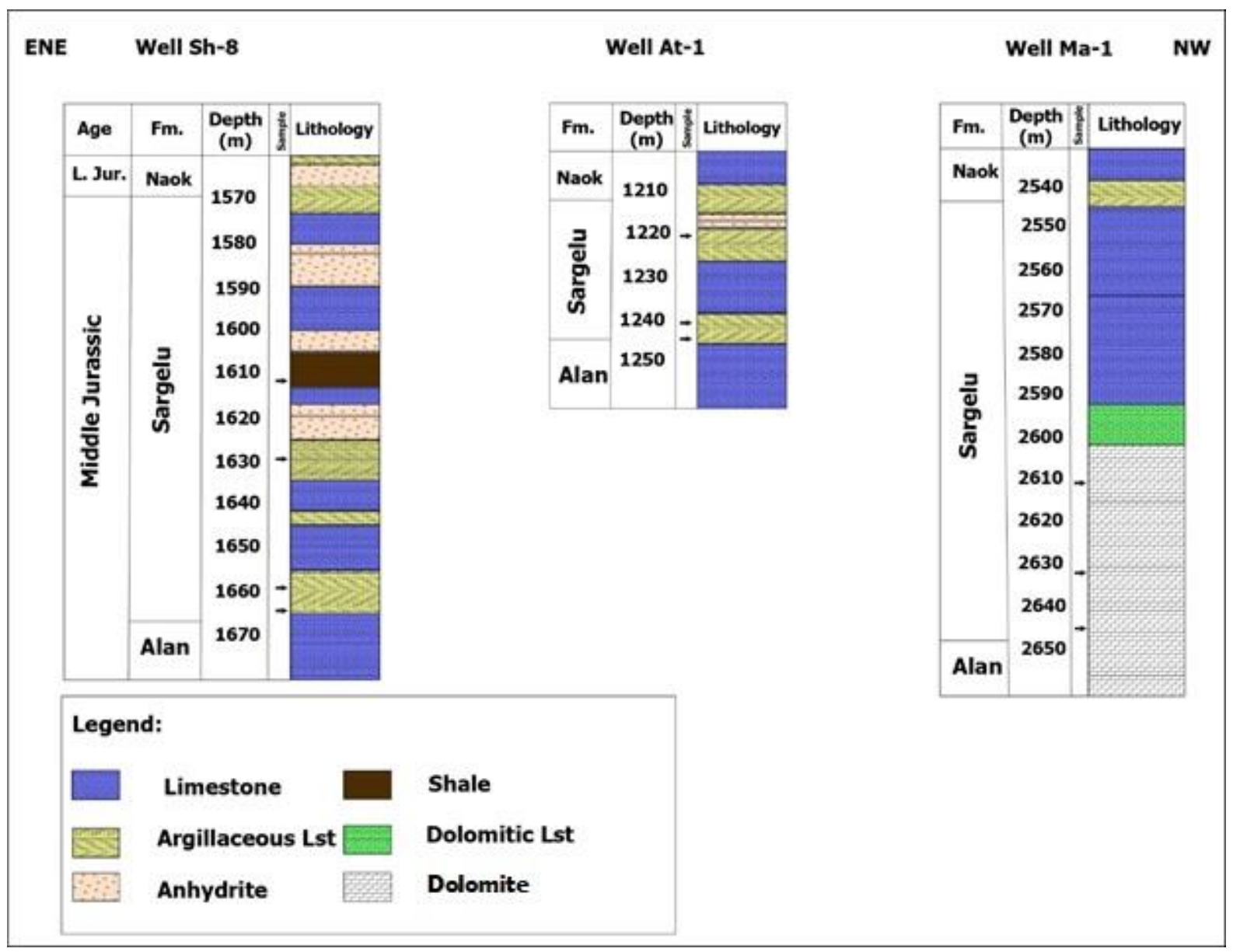

Fig. 3: Stratigraphic Columns of Sargelu Formation in Wells Ma-1, At-1 and Sh-8

\section{METHODOLOGY}

This study is mainly based on the analyses of cutting samples collected from shales, argillaceous limestone, and dolomite fraction selected from wells in the northwestern part of Iraqi Kurdistan Region (Fig. 3). The samples were picked from different stratigraphic levels, representing various depth intervals. There are ten cutting samples of the Sargelu Formation, it is from Wells Ma-1 (from depth 2545 to $2647 \mathrm{~m}$ ), At-1 (from depth 1212 to $1245 \mathrm{~m}$ ), and Sh-8 (from depth 1570 to $1666 \mathrm{~m}$ ). They were collected to pyrolysis analysis. These cuttings were stored at the Geological Survey Repository in Erbil City.

The utilized analytical techniques were pyrolysis and biomarker. Four samples were analyzed by GC, and three samples were used to stable carbon isotope and GC-MSS analysis. These analyses were performed by Strato Chem Laboratories, Cairo, Egypt, in collaboration with GeoMark Research, Ltd. in Houston, Texas, USA. 


\section{Pyrolysis}

The Rock-Eval pyrolysis data provides information on the quality, quantity and maturity level of OM of source rocks (Tissot and Welte, 1984 and Peters, 1986). Primarily, the samples were cleaned from contaminants from drilling mud additives by washing them with the distal water several times until no mud was visible on their surface. For the Rock-Eval Pyrolysis, a small amount of sample (100 mg) is heated in an inert atmosphere (helium or nitrogen) then combusted with air to acquire several key geochemical parameters related to the hydrocarbon potential of the rock such as TOC (Peters, 1986). TOC (wt.\%) is calculated as the sum of organic carbon and residual organic carbon.

Pyrolysis provides four geochemical parameters, including $\mathrm{S}_{1}$, which represents free and adsorbed hydrocarbons in $\mathrm{mg} \mathrm{HC/g}$ of rock, $\mathrm{S}_{2}$, which refers to generated hydrocarbons in $\mathrm{mg} \mathrm{HC} / \mathrm{g}$ of rock, $\mathrm{S}_{3}$, which provides $\mathrm{CO}_{2}$ released during the pyrolysis phase of the analysis in $\mathrm{mg} \mathrm{CO} / \mathrm{g}$ of rock, and $\mathrm{T}_{\max }$, which gives the temperature of maximum pyrolytic hydrocarbon yield in ${ }^{\circ} \mathrm{C}$. These primary parameters are used to deduce the values of TOC (wt.\%). The provided parameters can be used to differentiate the kerogen types and oil migration by using the following equations:

Oxygen Index $(\mathrm{OI})=\left(\mathrm{S}_{3} / \mathrm{TOC}\right) \times 100$, in $\mathrm{mg} \mathrm{CO} 2 / \mathrm{g}$ TOC

Hydrogen Index $(\mathrm{HI})=\left(\mathrm{S}_{2} / \mathrm{TOC}\right) \times 100$, in $\mathrm{mg} \mathrm{HC} / \mathrm{g}$ TOC

Production Index $(\mathrm{PI})=\mathrm{S}_{1} /\left(\mathrm{S}_{1}+\mathrm{S}_{2}\right)$

Genetic Potential $(\mathrm{GP})=\mathrm{S}_{1}+\mathrm{S}_{2}$, in $\mathrm{kg} \mathrm{HC} /$ ton of rock

\section{Gas Chromatography and Stable Carbon Isotope}

The GC analysis of saturated hydrocarbon fractions in the extracted bitumens was carried out using an Agilent 7890 chromatograph equipped with a flame ionization detector (FID). The oven temperature program included an initial rise from 70 to $300{ }^{\circ} \mathrm{C}$ at a rate of $3{ }^{\circ} \mathrm{C} / \mathrm{min}$, then held for $30 \mathrm{~min}$ at $300{ }^{\circ} \mathrm{C}$. Gas chromatography-mass spectroscopy (GC-MSS) analysis was accomplished for the saturated and aromatic fractions in the source rock extracts with an Agilent 7890A gas chromatograph coupled to an Agilent 5975C mass spectrometer. The gas chromatograph oven was initially run at $60{ }^{\circ} \mathrm{C}$ for $2 \mathrm{~min}$, programmed to $300{ }^{\circ} \mathrm{C}$ at $2{ }^{\circ} \mathrm{C} / \mathrm{min}$ and held at $300{ }^{\circ} \mathrm{C}$ for $30 \mathrm{~min}$. Bulk stable carbon isotope analysis was implemented for the saturated and aromatic hydrocarbon fractions by an online system utilizing a Finnigan delta plus mass spectrometer coupled with a Carlo Erba EA 1108 instrument. 


\section{RESULTS AND DISCUSSION}

The analysis results of TOC\% and Rock-Eval pyrolysis are given in Table 1, while those of stable carbon isotope composition, GC, and biomarker are shown in Table (2).

Table 1: Rock-Eval Pyrolysis and TOC results of Sargelu Formation in the studied wells

\begin{tabular}{|c|c|c|c|c|c|c|c|c|c|c|c|c|}
\hline Well & $\begin{array}{c}\text { Depth } \\
\text { (m) }\end{array}$ & $\begin{array}{l}\text { TOC } \\
\text { Wt } \%\end{array}$ & $\mathbf{S}_{1}$ & $\mathbf{S}_{2}$ & $\mathbf{S}_{3}$ & $\begin{array}{c}{ }^{\text {Tmax }}{ }^{\circ} \mathrm{C} \\
\end{array}$ & HI & OI & PI & GP & S1/TOC & $\begin{array}{l}\mathbf{R}_{\mathbf{0}} \\
\%\end{array}$ \\
\hline \multirow{3}{*}{ Ma-1 } & $2607-2610$ & 0.51 & 0.34 & 1.37 & 1.04 & 429 & 270 & 205 & 0. & 1.71 & 0.67 & 0. \\
\hline & $2628-2631$ & 0.62 & 0.50 & 2.01 & 0.86 & 430 & 325 & 139 & 0. & 2.51 & 0.81 & 0. \\
\hline & $2646-2649$ & 0.70 & 0.44 & 2.28 & 0.89 & 429 & 326 & 127 & 0. & 2.72 & 0.63 & 0. \\
\hline \multirow{3}{*}{ At-1 } & $1215-1220$ & 3.06 & 1.38 & 14.0 & 0.54 & 436 & 459 & 18 & 0. & 15.4 & 0.45 & 0. \\
\hline & $1235-1240$ & 8.59 & 2.80 & 47.7 & 0.71 & 438 & 555 & 8 & 0. & 50.5 & 0.33 & 0. \\
\hline & $1245-1250$ & 5.53 & 2.06 & 28.9 & 0.63 & 435 & 524 & 11 & 0. & 31.0 & 0.37 & 0. \\
\hline \multirow{4}{*}{ Sh-8 } & $1608-1611$ & 1.16 & 0.49 & 4.97 & 0.82 & 422 & 428 & 71 & 0. & 5.46 & 0.42 & 0. \\
\hline & $1626-1629$ & 4.16 & 1.89 & 18.8 & 0.72 & 436 & 454 & 17 & 0. & 20.7 & 0.45 & 0. \\
\hline & $1656-1659$ & 11.60 & 2.52 & 63.7 & 0.90 & 440 & 550 & 8 & 0. & 66.2 & 0.22 & 0. \\
\hline & $1661-1664$ & 4.48 & 1.43 & 23.9 & 0.72 & 436 & 535 & 16 & 0. & 25.3 & 0.32 & 0. \\
\hline
\end{tabular}

TOC = Total Organic Carbon, wt\%; $\mathbf{S}_{\mathbf{1}}=$ Free hydrocarbon content, $\mathrm{mg} \mathrm{HC} / \mathrm{g}$ rock; $\mathbf{S}_{2}$ : Remaining hydrocarbon generative potential, $\mathrm{mg} \mathrm{HC} / \mathrm{g}$ rock; $\mathbf{S}_{3}=$ Carbon dioxide yield, $\mathrm{mg} \mathrm{CO}_{2} / \mathrm{g}$ rock; $\mathbf{T}_{\max }=$ Temperature at maximum of $\mathrm{S}_{2}$ peak; $\mathbf{H I}$ : Hydrogen Index $=\mathrm{S}_{2} \times 100 / \mathrm{TOC}, \mathrm{mg} \mathrm{HC} / \mathrm{g}$ TOC; OI: Oxygen Index $=\mathrm{S}_{3} \times 100 / \mathrm{TOC}, \mathrm{mg} \mathrm{CO}_{2} / \mathrm{g}$ TOC; PI: Production Index = $\mathrm{S}_{1} /\left(\mathrm{S}_{1}+\mathrm{S}_{2}\right) ;$ GP: Genetic Potential $=\left(\mathrm{S}_{1}+\mathrm{S}_{2}\right), \mathrm{Kg} \mathrm{HC} / \mathrm{Ton}$ rock; $\mathbf{R}_{\mathbf{0}}=$ Calculated Vitrinite Reflectance.

Table 2: Gas Chromatograph-Mass Spectrometry coupled with Isotope data

\begin{tabular}{|c|c|c|c|c|c|c|c|c|c|c|c|c|}
\hline Well & $\begin{array}{c}\text { Depth } \\
\text { (m) }\end{array}$ & $\begin{array}{c}\text { Sample } \\
\text { weight }\end{array}$ & $\begin{array}{l}\delta^{13} C_{\text {Sat. }} \\
\text { (\%) }^{(\text {a) }}\end{array}$ & $\begin{array}{c}\delta^{13} C_{\text {Aro- }} \\
(\%))^{(b)}\end{array}$ & $\mathrm{CV}$ & $\mathrm{Pr} / \mathrm{ph}$ & $\begin{array}{c}\mathrm{Pr} / \mathrm{n}- \\
\mathrm{C}_{17}\end{array}$ & $\begin{array}{c}\mathrm{Ph} / \mathrm{n}- \\
\mathrm{C}_{18}\end{array}$ & CPI & $\begin{array}{c}\mathrm{C}_{27} \% \\
\text { Sterane }\end{array}$ & $\begin{array}{c}\mathrm{C}_{28} \% \\
\text { Sterane }\end{array}$ & $\begin{array}{c}\mathrm{C}_{29} \% \\
\text { Sterane }\end{array}$ \\
\hline Ma-1 & 2631 & 75.70 & -27.50 & -27.20 & -2.47 & 0.66 & 0.24 & 0.28 & 0.86 & 55.90 & 16.00 & 28.10 \\
\hline At-1 & 1240 & 90.00 & -29.50 & -28.40 & -2.28 & 0.63 & 0.21 & 0.42 & 0.94 & 54.20 & 15.50 & 30.30 \\
\hline \multirow[b]{2}{*}{ Sh-8 } & 1629 & 62.40 & & & & 0.58 & 0.34 & 0.53 & 0.94 & & & \\
\hline & 1664 & 96.10 & -28.20 & -28.10 & -2.68 & 0.62 & 0.32 & 0.46 & 0.93 & 53.20 & $\begin{array}{l}14.70 \\
\end{array}$ & 32.10 \\
\hline
\end{tabular}

${ }^{(a)}{ }^{13} C_{\text {Sat. }}=$ Stable Carbon isotopic composition of the Saturated HC fraction

(b) $\delta^{13} \mathrm{C}_{\text {Aro. }}=$ Stable Carbon isotopic composition of the Aromatic HC fraction

\section{Organic Matter Richness and Petroleum Potential}

The TOC\% versus $S_{1}$ plot of Hunt (1996), applied to the studied samples of Sargelu Formation, shows that they are not contaminated and of indigenous origin (Fig. 4a). The TOC\% content of the sediments can be considered as a direct expression of kerogen and bitumen abundance (Hunt, 1996). Sediments with TOC\% values of 0.5 to 1.0 wt.\% are considered as potential source rocks (Tissot and Welte, 1984; Tissot et al., 1987; Hunt, 1996). The result show that TOC\% ranges from 0.51 to $11.6 \mathrm{wt} . \%$ (average = 4.04 wt.\%) (Table 1). 

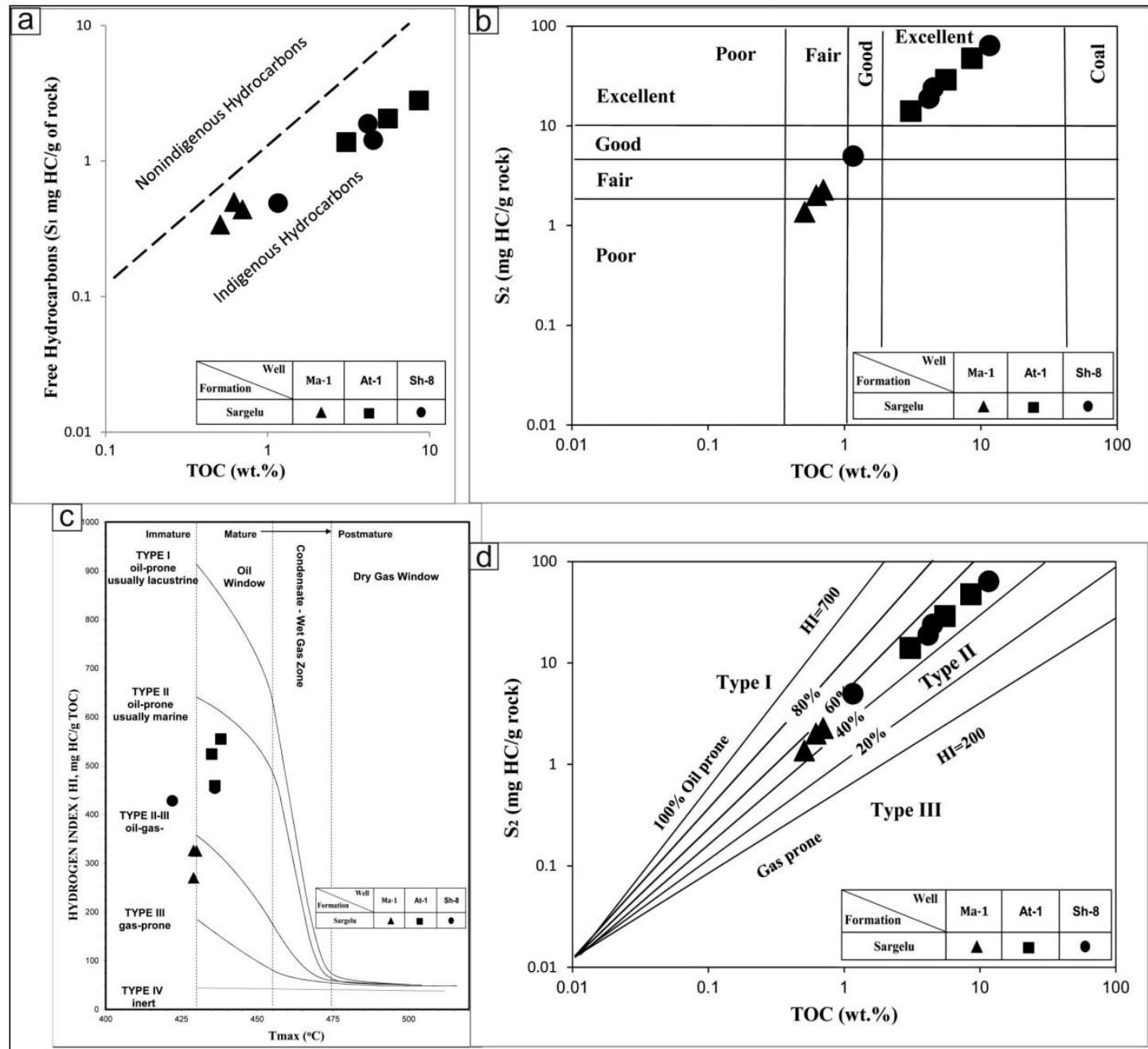

Fig. 4: (a) TOC\% versus $S_{1}$ for identifying migrated hydrocarbons for Sargelu Fn.

(b) Pyrolysis $S_{2}$ versus TOC\% plot showing generative source rock potential

(c) HI versus Pyrolysis $T_{\max }$ for the analyzed samples

(d) Plot of Pyrolysis $\mathrm{S}_{2}$ versus TOC\% shows the kerogen type of the studied samples. The plot also indicates whether kerogen is oil or gas prone

Most of the samples have fair to excellent genetic potential (GP) based on the classification given by Peters and Cassa (1994) (Fig. 4b), and the GP contents range from 1.71 to $66.27 \mathrm{~kg} \mathrm{HC} /$ ton of rock (average $=22.17 \mathrm{~kg} \mathrm{HC} /$ ton of rock). Samples of Ma-1 well have poor GP, averaging $2.47 \mathrm{~kg} \mathrm{HC} / \mathrm{ton}$ of rock. On the other hand, samples of At-1 and Sh-8 wells have excellent GP, with an average $32.32 \mathrm{~kg}$ $\mathrm{HC} / \mathrm{ton}$ of rock and $29.47 \mathrm{~kg} \mathrm{HC} /$ ton of rock, respectively (Table 1). The hydrocarbon yields $\left(\mathrm{S}_{2}\right)$ are in 
agreement with TOC\% content in At-1 and Sh-8 wells, indicating that the Sargelu sediments are excellent source rock on the contrary of Ma-1 well (Fig. 4b).

\section{Quality of Organic Matter}

Type II kerogen generates oil, while Type III kerogen produces gas, if the source rock was buried deeply enough (Hunt, 1996). The HI versus $\mathrm{T}_{\max }$ plot of Van Krevelen applied on the studied samples indicated the presence of kerogen Type II for At-1 and Sh-8 wells with mixed kerogen Types II and III for Ma-1 well (Fig. 4c). Most of the samples are placed within oil window field; however, two samples from Ma1 well and one from Sh-8 well behaved differently as they were placed in the areas of early maturation stage and immature stage, respectively (Fig. 4c), owing to their low $\mathrm{T}_{\max }$ values $\left(<430^{\circ} \mathrm{C}\right)($ Table 1$)$.

The results of the analysis show that the HI ranges from 270 to $555 \mathrm{mg} \mathrm{HC} / \mathrm{g}$ TOC. Most HI values of Sargelu Formation samples are > $300 \mathrm{mg} \mathrm{HC} / \mathrm{g}$ TOC, illustrating Type II kerogen source with except one sample from Ma-1 well, that has a $\mathrm{HI}<300 \mathrm{mg} \mathrm{HC} / \mathrm{g}$ TOC, which is more likely as a mixture of Types II and III kerogen.

Rock-Eval pyrolysis $\mathrm{T}_{\max }$ values of the Sargelu Formation samples range from 422 to $440{ }^{\circ} \mathrm{C}$. Such $\mathrm{T}_{\max }$ values are considered as low for Type I kerogen, high for Type II and much higher for Type III kerogen. The reason for such variations is due to the structural complexities of OM (Tissot and Welte, 1984, Peters, 1986 and Bordenave et al., 1993).

Rock-Eval Pyrolysis suggests that variations among the results are considerable because of the limestone- and dolostone-dominated rocks for Sargelu Formation. Carbonate rocks commonly affect the OI, thus lowering the identification of kerogen types within the formation (Abdula, 2015). The high values of $\mathrm{OI}$ in Ma-1 well samples (Table 1) indicate possible oxidation has taken place during the generation of $\mathrm{HC}$, creating oxic conditions in the depositional environment.

The $S_{2}$ versus TOC plot shows that most of Sargelu Formation samples tend to be Type II Kerogen with different levels of oil and gas prone (Fig. 4d). In general, the results show different kerogen types, with a tendency toward Type II in the majority of the Sargelu Formation samples (Figs. 4a, b, c and d).

The calculated Vitrinite Reflectance $\left(\mathrm{R}_{\mathrm{o}}\right)$ values, obtained by converting $\mathrm{T}_{\max }$ (Peters et al., 2005). $\mathrm{R}_{\mathrm{o}}($ calculated $)=\left(0.018 \times \mathrm{T}_{\max }\right)-7.16$

In order to get the real value of $R_{0}$, the above formula was used for samples that have $S_{2}$ values > $0.5 \mathrm{mg} \mathrm{HC} / \mathrm{g}$ rock and $\mathrm{T}_{\max }>420$ or $<500{ }^{\circ} \mathrm{C}$. 
The expelled oil from source rocks starts when the ratio of $S_{1}$ to TOC ranges between 0.1 and 0.2 (Hunt, 1996). All S 1 /TOC values of Sargelu Formation are $>0.2$ (Table 1). Therefore, the expulsion of oil from Sargelu Formation occurred at depths shallower than where it exists; 2607 m, 1215 m, and 1608 $\mathrm{m}$ in Ma-1, At-1, and Sh-8 wells, respectively.

\section{Normal Alkanes and Isoprenoids}

The $\mathrm{Pr} / \mathrm{Ph}$ ratio is frequently used as an indicator of the depositional environment and maturity detection (Peters et al., 2005). When this ratio is $(<1)$, this would be used as a proxy to indicate reducing or anoxic conditions of carbonate source rocks, mainly when followed by the high prophyrin and sulfur contents (Peters and Moldowan, 1993). The lower pristane (Pr) content within a sample is mainly attributed to reducing the environment, however, the higher $\mathrm{Pr} / \mathrm{Ph}$ ratio has likely caused oxygenic environment at the deposition time of source rock (Ten Haven et al., 1987).

The organic-rich anoxic carbonate rocks generally generate oil with $\mathrm{Pr} / \mathrm{Ph}$ ratio of $<2$ (Peters et al., 2005). The ratios of the $\mathrm{Pr} / \mathrm{Ph}$ of the four extracts are low, ranging between 0.58 to 0.66 , indicating anoxic, reduced marine carbonate depositional environment (Fig. 5).

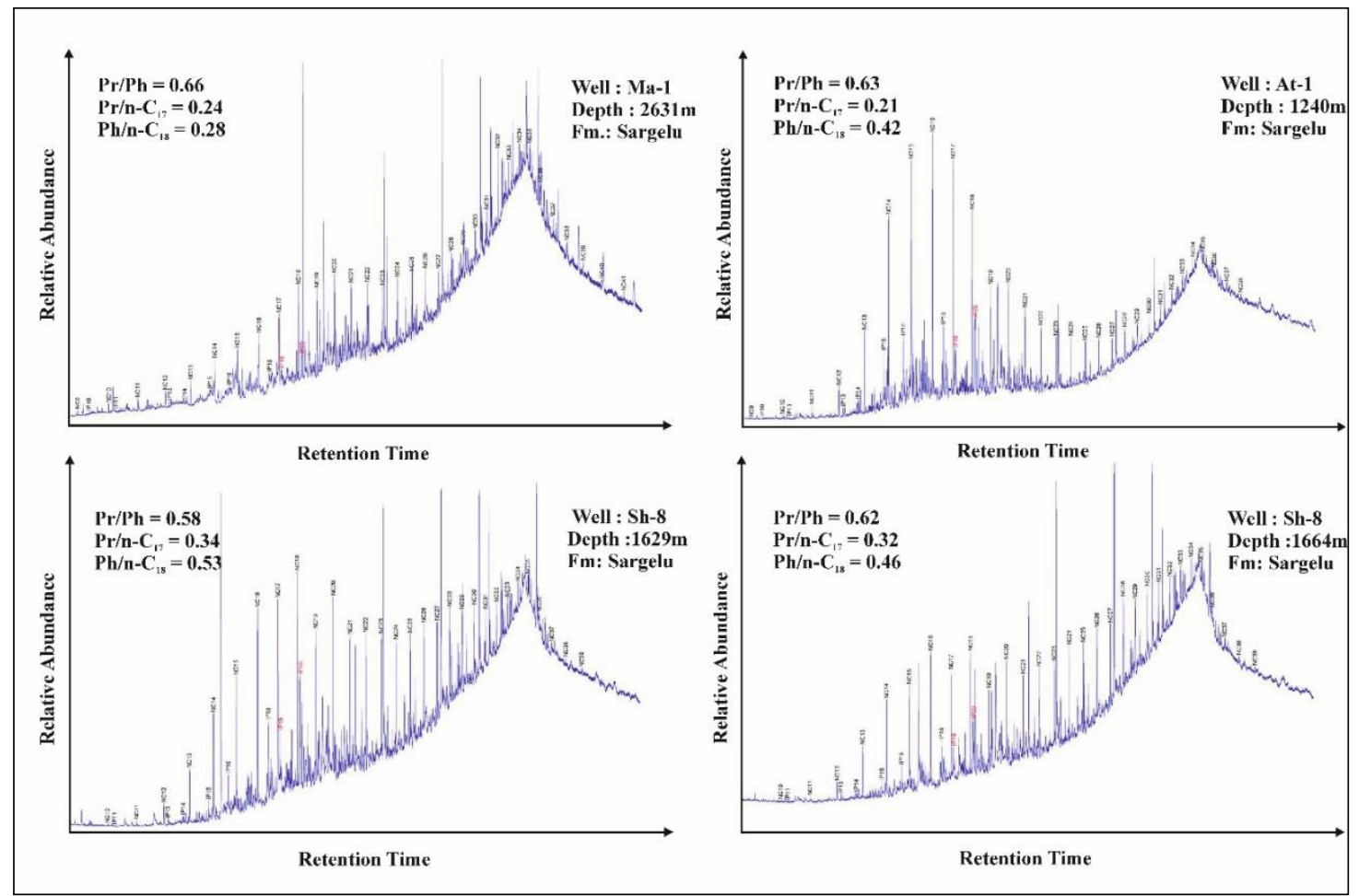

Fig. 5: Gas Chromatographs of extracted rock samples from Sargelu Formation, NW Iraq 
All extract samples show large unresolved complex mixture (UCM) or hump, where the n-alkanes and isoprenoids still survive and remain unaltered. These samples appear to have suffered from excessive evaporation where $\mathrm{Pr}$ and $\mathrm{Ph}$ still retain their characters.

The $\mathrm{Pr} / \mathrm{n}-\mathrm{C}_{17}(0.21$ to 0.34$)$ and $\mathrm{Ph} / \mathrm{n}-\mathrm{C}_{18}$ (0.28 to 0.53$)$ ratios (Table 2) suggest primary accumulation of marine organic matter under reducing conditions instead of maturity effect or biodegradation for extracts (Fig. 6).

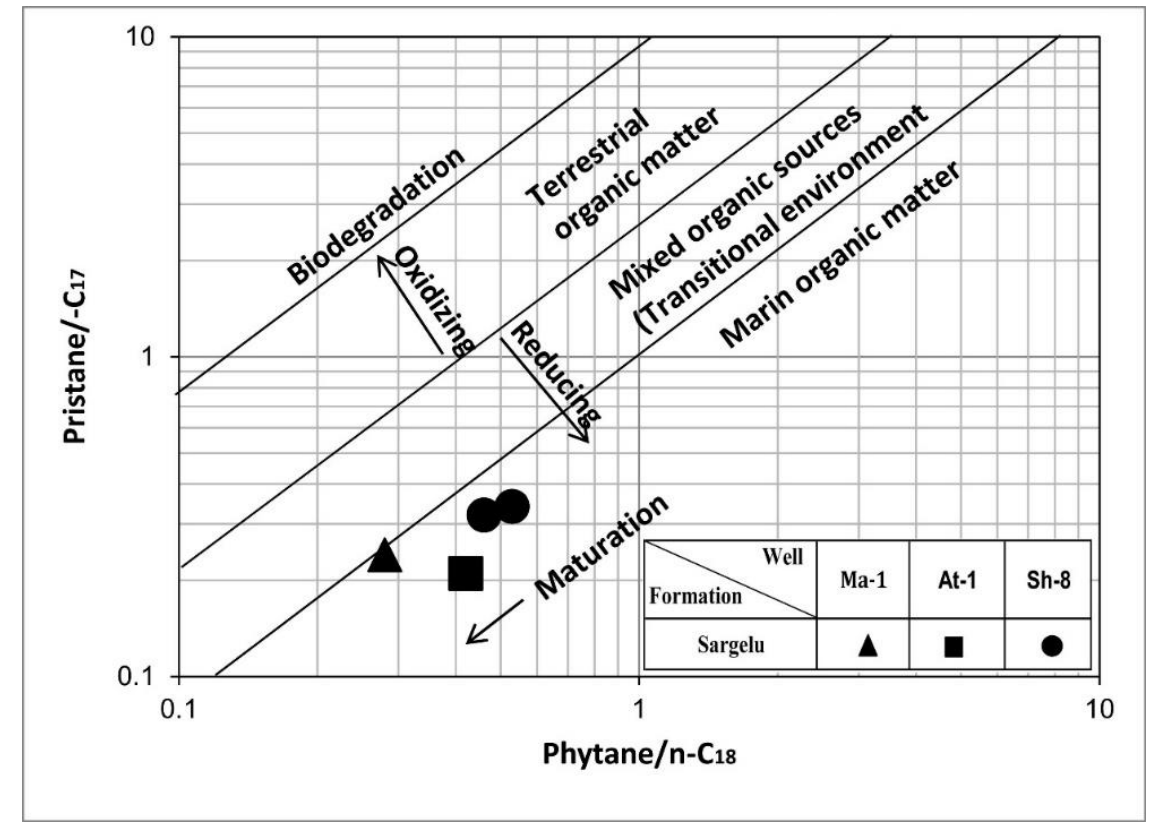

Fig. 6: $\mathrm{Pr} / \mathrm{n}-\mathrm{C}_{17}$ versus $\mathrm{Ph} / \mathrm{n}-\mathrm{C}_{18}$ of the Sargelu Formation samples extract for the studied wells

The carbon preference index (CPI) can be used as a maturity indicator (Peters et al., 2005).

$$
C P I=2\left(C_{23}+C_{25}+C_{27}+C_{29}\right) /\left[C_{22}+2\left(C_{24}+C_{26}+C_{28}\right)+C_{30}\right] \ldots
$$

For instance, immature source rocks have CPI values $>1.2$ or < 0.8 (Moldowan et al., 1985). CPI values below 1.0 are rare and indicate extracts formed in hypersaline or carbonate environments (Peters et al., 2005). The calculated CPI of the extracts of Sargelu Formation were $<1.2$ and $>0.8$ (Table 2), indicating marine carbonate environment and maturation stage.

\section{Sable Carbon Isotopes Composition $\left(\delta^{13} \mathrm{C}_{\%}\right)$}

The isotope composition of the extracted bitumen from saturates and aromatics fraction can be used to distinguish between oxic terrigenous and an anoxic marine environment by applying a mathematical relation known as canonical variable (CV), (Sofer, 1984). 


$$
C V=-2.53 \delta^{13} C_{S a t}+2.22 \delta^{13} C_{\text {Aro }}-11.65
$$

Values of $\mathrm{CV}>0.47$ indicate predominant terrigenous organic matter, while $\mathrm{CV}<0.47$ indicates mostly marine organic source. The calculated CV of the studied extracts ranges from -2.68 to -2.28 (Table 2), which confirms the prevailing marine environment.

Additionally, carbon isotope values of saturates $\left(\delta^{13} \mathrm{C}_{\text {Sat }}\right)$ and aromatics $\left(\delta^{13} \mathrm{C}_{\text {Aro }}\right)$ for three rock extract samples within Sargelu Formation range from -27.5 to $-29.5 \%$ and -27.2 to

$-8.4 \%$, respectively (Table 2 ). These values display a slight variation in the isotopic composition of the extracted samples (Demaison and Huizinga, 1991) and confirm that the OM within the studied formation was mainly derived from the marine origin (Fig. 7).

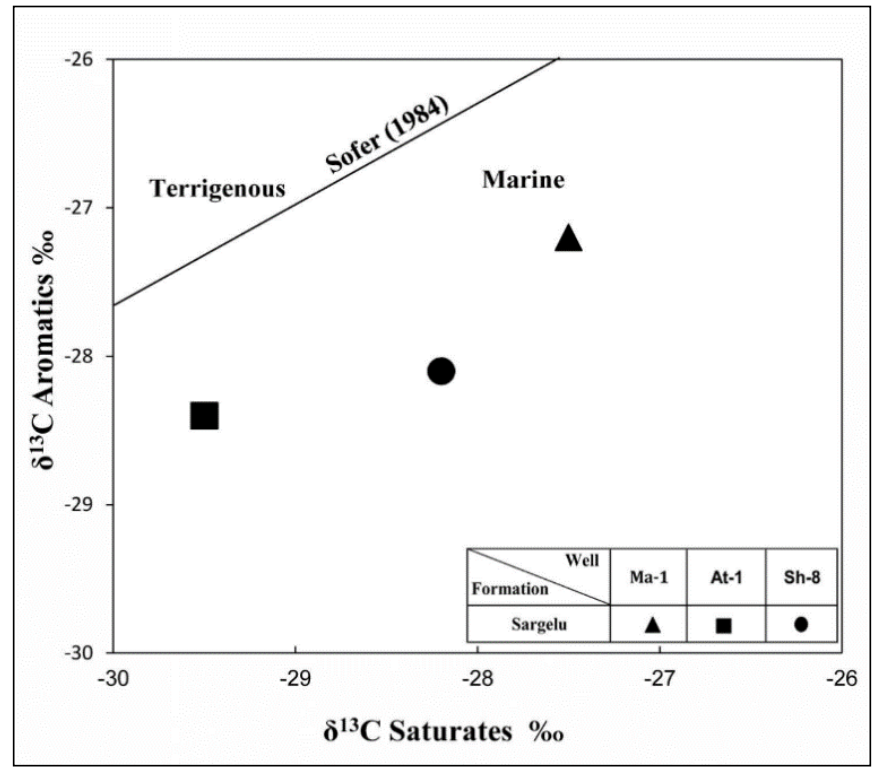

Fig. 7: Isotope $\delta^{13} \mathrm{C}$ from Saturate versus $\delta^{13} \mathrm{C}$ Aromatic cross plot for the analyzed studied samples extract

The ternary diagram of $\mathrm{C}_{27} \%-\mathrm{C}_{28} \%-\mathrm{C}_{29} \%$ steranes compounds from the extracts of source rocks were frequently used to identify the type or origin of the initial OM. The main sources of $\mathrm{C}_{27}$ steranes are of marine origin, and that of $\mathrm{C}_{29}$ steranes are mostly derived from advanced plants. The $\mathrm{C}_{28}$ steranes consist of a mixture of advanced plants and mainly algae (Peters et al., 2005). The examined samples, including rock-extract of Sargelu Formation, are characterized by the abundance of $\mathrm{C}_{27}$ over $\mathrm{C}_{28}$ and $\mathrm{C}_{29}$ (Fig. 8), which proves deposition was done in the marine environment (Fig. 9). 

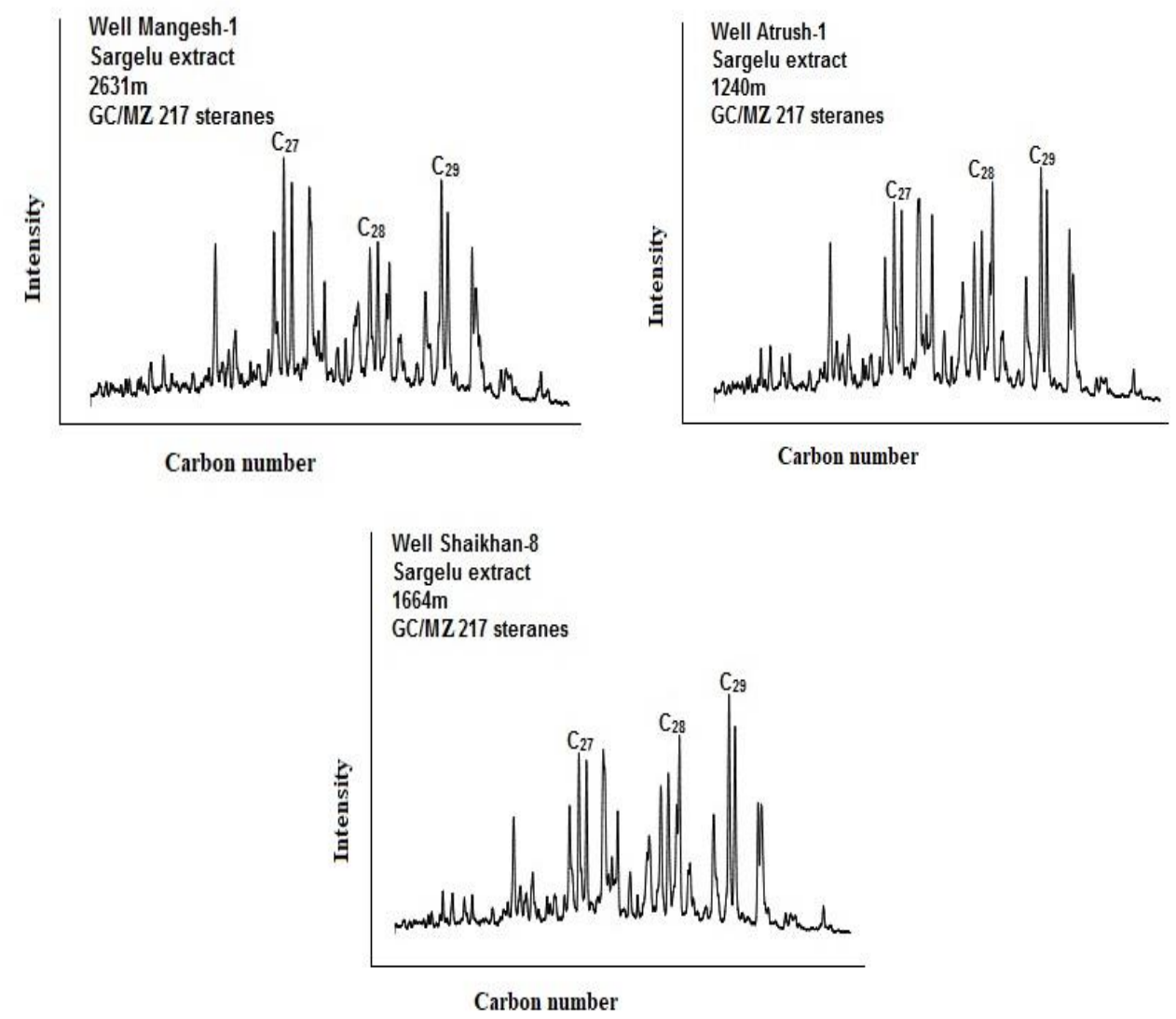

Fig. 8: Mass Chromatograms of Steranes, $\mathrm{m} / \mathrm{z} 217$, from the extract of the studied sample

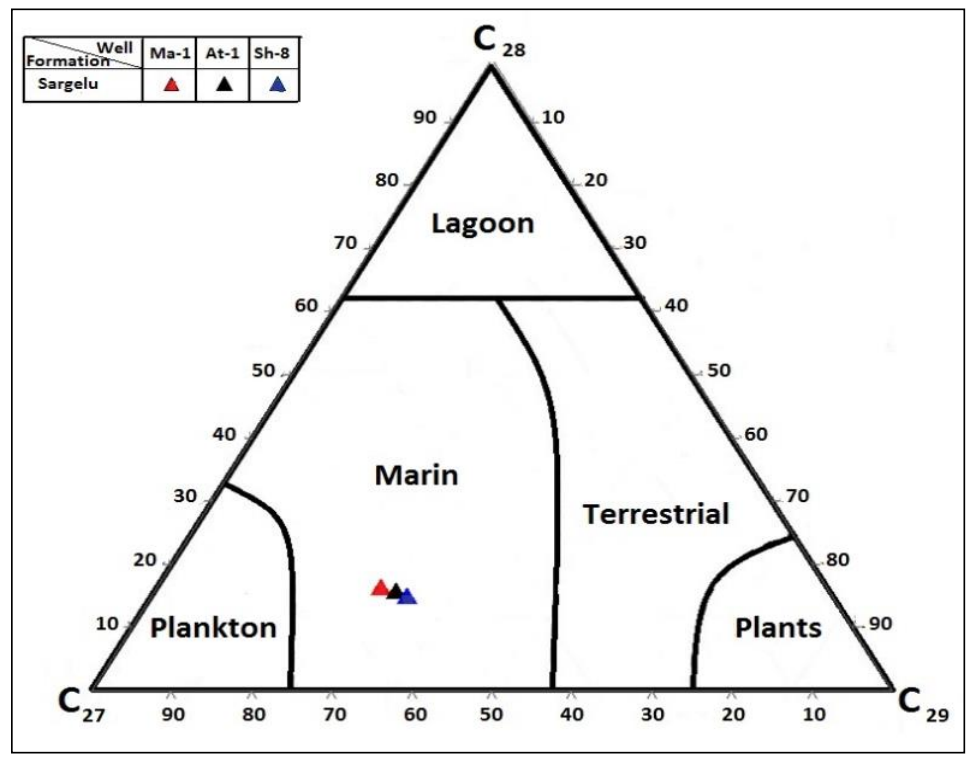

Fig. 9: Steranes Ternary Diagram of $\mathrm{C}_{27} \%, \mathrm{C}_{28} \%$ and $\mathrm{C}_{29} \%$ of the selected extract samples using GC-MSS m/z 217 


\section{CONCLUSIONS}

The following conclusions could be drawn from the results of organic geochemistry and biomarker studies of the Middle Jurassic Sargelu Formation samples taken from three exploration wells drilled in NW Iraqi Kurdistan .

(1) The OM of Sargelu Formation was kerogen Types II and mixed II/III, that the kerogen thermally mature and frequently located within the oil generation zone.

(2) The studied samples were characterized by marine OM dominated with high TOC\% contents.

(3) The isoprenoids ratio of $\mathrm{Pr} / \mathrm{Ph}$ range was between (0.58 to 0.66), $\mathrm{Pr} / \mathrm{n}-\mathrm{C}_{17}$ (0.21 to 0.34$)$ and $\mathrm{Ph} / \mathrm{n}-\mathrm{C}_{18}$ (0.28 to 0.53$)$, of the extracts, are low, indicating mature with anoxic, reducing marine carbonate depositional origin.

(4) Stable isotopic ratios of the saturate and aromatic fractions, expressed as a Ternary plot between regular $\mathrm{C}_{27} \%-\mathrm{C}_{28} \%-\mathrm{C}_{29} \%$, steranes, revealed that the existing $\mathrm{OM}$ is mainly derived from the marine depositional environment.

\section{ACKNOWLEDGMENTS}

The authors thank the Strato Chem Laboratories, Cairo, Egypt for their technical support. Thanks are extended to the authorities of the Ministry of Natural Resources - Geological Survey in Erbil for providing cutting samples. Many thanks for Professor Yawooz Kettanah, Duhok University, for revising the manuscript.

\section{REFERENCES}

Abdula, R.A., 2015. Hydrocarbon potential of Sargelu Formation and oil-source correlation, Iraqi Kurdistan. Arabian Journal of Geosciences, 8:5845-5868.

Al-Ameri, T.K. and Zumberge, J., 2012. Middle and Upper Jurassic hydrocarbon potential of the Zagros Fold Belt, North Iraq. Marine and Petroleum Geology, 36:13-34.

Al-Ameri, T.K., Najaf, A.A., Al-Khafaji, A.S., Zumberge J., Pitman, J., 2013. Hydrocarbon potential of the Sargelu Formation, North Iraq. Arabian Journal of Geosciences, 7:987-1000.

Al-Azzawi, N.K., Hamdoon, A.N., 2008. Structure and geomorphology of Shaikhan Anticline- Northern Iraq. Iraqi National Journal of Earth Sciences, 8:54-63.

Al-Naqib, S.O., 1980. Geology of Atrush area. M.Sc. Thesis, University of Mosul, Iraq,110 pp.

Ameen, M.S., 1992. Effect of basement tectonics on hydrocarbon generation, migration and accumulation in northern Iraq. American Associations of Petroleum Geologists Bulletin, 76:356-370.

Balaky, S.M.H., 2004. Stratigraphy and sedimentology of Sargelu Formation (Middle Jurassic) in selected sections in Erbil and Duhok Governorates, Iraqi Kurdistan. M.Sc. Thesis, Salahaddin University, Erbil, 109 pp. 
Bellen, R.C., Dunnington, H.V., Wetzel, R., and Morton, D., 1959. Lexique stratigraphic international, Asie, Iraq. International Geological Congress. Fasc. 10a. Paris: International Commission on Stratigraphy, 311 pp.

Beydoun, Z.R., 1986. The petroleum resources of the Middle East: a review. Journal of Petroleum Geology, 9:5-27.

Bordenave, M.L., Espitalie, J., Laplat, P., Oudin, J.L., and Vandenbrouke, M., 1993. Screening techniques for source rock evaluation. Applied Petroleum Geochemistry, Editions Technip, Paris.

Buday, T., 1980. The Regional Geology of Iraq, Stratigraphy and Paleontology. Dar Al-Kutub Publishing House, Mosul, 335 pp.

Demaison, G., and Huizinga, B. J., 1991. Genetic classification of petroleum systems, American Associations of Petroleum Geologists Bulletin, 75:1626-1643.

English, J.M., Lunn, G.A., Ferreira L., and Yacu, G., 2015. Geologic evolution of the Iraqi Zagros, and its influence on the distribution of hydrocarbons in the Kurdistan Region, American Associations of Petroleum Geologists Bulletin, 99:231-272.

Hakimi, M.H., and Najaf, A.A., 2016. Origin of crude oils from oilfields in the Zagros Fold Belt, southern Iraq. Relation to organic matter input and paleoenvironmental conditions. Marine and Petroleum Geology, 78: 547-561.

Hunt, J.M., 1996, Petroleum Geochemistry and Geology, second ed. Freeman and Company, New York.

Jassim, S.Z., and Buday, T., 2006. Late Toarcian-Early Tithonian (Mid-Late Jurassic) Megasequence AP7, Chapter 10. In: Jassim S.Z., Goff, J.C. (eds.), Geology of Iraq. Dolin, Prague, 117-123.

Jassim, S.Z., and Goff, J.C., 2006. Geology of Iraq. Dolin, Prague.

Moldowan, J.M., Seifert, W.K., and Gallegos, E.J., 1985. Relationship between petroleum composition and depositional environment of petroleum source rock: American Associations of Petroleum Geologists Bulletin, 69:1255-1268.

Murris, R.J., 1980. Hydrocarbon habitat of the Middle East. In: Miall, A.D. (ed.), Facts and principles of world petroleum occurrence. Canadian Society of Petroleum Geologists Memoir 6:765-800.

Peters, K.E., 1986. Guidelines for evaluating petroleum source rocks using programmed pyrolysis. American Associations of Petroleum Geologists Bulletin, 70:318-329.

Peters, K.E., and Moldowan, J.M., 1993. The Biomarker Guide: Interpreting Molecular Fossils in Petroleum and Ancient Sediments, Prentice Hall, New Jersey.

Peters, K.E., and Cassa, M.R., 1994. Applied source rock geochemistry. In: Magoon, L.B., and Dow, W.G. (eds.), The petroleum system from source to trap. American Associations of Petroleum Geologists Memoir, 60:93-120.

Peters, K.E., Walters, C.C. and Moldowan, J.M., 2005. The Biomarker Guide; Biomarkers and Isotopes in Petroleum Exploration and Earth history. Cambridge University Press.

Sitman, J.K., Steinshouer, D.W., and Lewan, M.D., 2004. Petroleum generation and migration in the Mesopotamian Basin and Zagros Fold Belt of Iraq, results from a basin modeling study. GeoArabia, Gulf PetroLink. Bahrain, 9:41-72.

Sofer, Z., 1984. Stable carbon isotope compositions of crude oils: application to source depositional environments and petroleum alteration. American Associations of Petroleum Geologists Bulletin, 68:31-49.

Ten Haven, H.L., De Leeuw, J.W., Rullkötter, J., and Damste, J.S., 1987. Restricted utility of the pristane/phytane ratio as a palaeoenvironmental indicator. Nature, 330:641-643.

Tissot, B.P., and Welte, D.H., 1984. Petroleum Formation and Occurrence. second ed. Springer-Verlag, New York.

Tissot, B.P., Pelet, R., Ungerer, P.H., 1987. Thermal history of sedimentary basins, maturation indices and kinetics of oil and gas generation. American Associations of Petroleum Geologists Bulletin, 71:1445-1466.

Waples, D.W., 1985. Geochemistry in Petroleum Exploration, International Human Resources Development Corporation, Boston. 